\title{
Aplikasi Xanthan Gum Pada Pengolahan Susu Tempe
}

\section{Application of Xanthan Gum in Tempe Milk Processing}

\author{
Asniwati Zainuddin', Mariani H. Mansyur'2, Cocan Djibu Moha ${ }^{1}$ \\ ${ }^{1}$ Teknologi Hasil Pertanian Universitas Ichsan Gorontalo \\ J. Achmad Nadjamuddin No. 17 Kota Gorontalo \\ ${ }^{2}$ Teknologi Pertanian Universitas Cokroaminoto Makassar \\ Л. Perintis Kemerdekaan Km. 11 Kota Makassar \\ asni.zainuddin@gmail.com
}

\begin{abstract}
Abstrak
Susu tempe merupakan produk hasil ekstraksi tempe dengan air sehingga diperoleh larutan dengan komponen padatan terlarut. Pada proses pembuatan susu tempe, ditambahkan bahan penstabil yaitu xanthan gum. Tujuan penelitian untuk mengetahui hasil analisis stabilitas, kadar protein, dan kadar air pada susu tempe dengan penambahan xanthan gum dan mengetahui hasil analisa organoleptik pada susu tempe dengan penambahan xanthan gum. Penelitian ini menggunakan Rancangan Acak Lengkap (RAL) dengan 5 perlakuan dan 3 kali ulangan. Hasil analisa yang diperoleh adalah kadar air $\mathrm{P0}=80,58 \%, \mathrm{P} 1=78,64 \%, \mathrm{P} 2=78,18 \%, \mathrm{P} 3=$ $77,24 \%$, dan $\mathrm{P} 4=76,87 \%$. Kadar protein $\mathrm{P0}=8,86 \%, \mathrm{P} 1=14,2 \%, \mathrm{P} 2=$ $14,2 \%$, P3 $=13,01 \%$, dan P4 = 9,56\%. Stabilitas P0 =96,00\%, P1 = 96,52\%, $\mathrm{P} 2=97,01 \%$, P3 $=97,51 \%$, dan P4 = 98\%. Jumlah xanthan gum pada perlakuan P2 $(0,25 \mathrm{~g}$ xanthan gum) lebih diterima panelis uji organoleptik baik aroma dan rasa.
\end{abstract}

Kata kunci : susu tempe; tempe; xanthan gum

\begin{abstract}
Tempe milk is the product of the extraction of tempe with water so obtained solution with total dissolved solid. Xanthan gum was added in tempe milk production, tempe added the stabilizer namely xanthan gum. The research purposes were to know stability, protein concentration, water content in tempe milk after addition of xanthan gum and to evaluate organoleptic quality of tempe milk with xanthan gum. This research used design complete ral (5) with treatment and 3 in time. The results of analysis showed that the water content of $P O=80,58 \%, P 1=78,64 \%, P 2=78,18 \%, P 3=77,24 \%$, and $P 4=76,87 \%$. protein content $P O=8,86 \%, P 1=14,2 \%, P 2=14,2 \%, P 3=13,01 \%$, and $P 4=$ 9,56\%. The stability $P O=96,00 \%, P 1=96,52 \%, P 2=97,01 \%, P 3=97,51 \%$, and P4 $=98 \%$. The addition of xantan gum in P2 treatment ( 0,25 g xanthan gum ) was most accepted by panelist, both in taste and flavor.
\end{abstract}

Keywords: tempe; tempe milk; xanthan gum

\section{PENDAHULUAN}

Indonesia merupakan negara produsen tempe terbesar di dunia dan menjadi pasar kedelai terbesar di Asia. Sebanyak 50\% dari konsumsi kedelai di Indonesia dalam bentuk tempe, $40 \%$ tahu dan 10\% dalam bentuk produk lain (seperti tauco, kecap, dan lain-lain). Konsumsi tempe rata-rata per orang per tahun di Indonesia 
saat ini sekitar 6,45 kg (Astawan, 2004). Tempe diminati oleh masyarakat Indonesia karena harganya relatif murah dan rasanya enak, serta memiliki kandungan protein nabati yang tinggi. Melalui proses pembuatan tempe, kedelai menjadi lebih enak dimakan dan meningkat nilai gizinya akibat aktivitas enzim proteolitik selama proses fermentasi kedelai menjadi tempe. Tempe yang masih baik (baru) memiliki rasa dan bau yang spesifik.

Menurut Mujianto (2013), tempe merupakan produk olahan kedelai yang nilai gizinya menjadi meningkat terutama protein, lemak, karbohidrat dan vitamin. Kandungan gizi tempe juga menjadi mudah larut dalam air sehingga mudah dicerna dibandingkan kedelai. Keuntungan lainnya yaitu proses produksi tempe merusak zat-zat anti nutrisi pada kedelai. Tempe memiliki daya simpan yang rendah dan mudah rusak. Tempe segar yang disimpan pada suhu ruang hanya bertahan dua hari sedangkan penyimpanan suhu rendah bertahan satu minggu. Dalam upaya peningkatan nilai tambah dan sifat organoleptik tempe perlu dilakukan upaya diversifikasi pengolahan tempe, salah satunya pembuatan susu tempe.

Susu tempe merupakan produk hasil ekstraksi tempe dengan air sehingga diperoleh larutan dengan komponen padatan terlarut. Susu tempe adalah salah satu produk generasi kedua tempe selain tepung tempe, bubur bayi, biskuit, es krim, burger, sosis dan produk lain yang tidak lagi mempunyai bentuk khas tempe (Widowati, 2005). Hapsari (2013) mengemukakan bahwa prinsip pembuatan sari tempe adalah ekstraksi tempe dengan air melalui tahap pembuatan yaitu pemotongan bentuk dadu, pengukusan 3 menit, penambahan air mendidih, penggilingan, penyaringan, penambahan bahan tambahan pangan (gula, garam, perisa, penstabil), dan pemanasan pada suhu $90^{\circ} \mathrm{C}$. Susu tempe yang dihasilkan dipengaruhi oleh proses fermentasi tempe. Selama periode fermentasi, terjadi perubahan karakteristik keseluruhan bahan dari kedelai menjadi tempe.

Menurut Nouts and Kiers (2005), selama periode fermentasi tempe, Rhizopus menghasilkan enzim karbohidrase, lipase, protease, phytase yang menghidrolisis komponen kimia. Enzim tersebut memecah makromolokul menjadi komponen yang mempunyai berat molekul $(\mathrm{BM})$ rendah, dan menyebabkan dinding sel serta komponen dalam sel sebagian larut. Berbagai macam polikasarida mempunyai komponen berat molekul tinggi larut dibebaskan oleh degradasi enzim. Perubahan juga terjadi pada kadar protein terlarut dan terjadi peningkatan kadar asam amino bebas dalam bahan.

Nouts and Kiers (2005) menambahkan perubahan yang terjadi selama fermentasi tempe antara lain peningkatan $\mathrm{pH}$ dari 5.0 menjadi 7.6. Peningkatan $\mathrm{pH}$ ini terjadi akibat pertumbuhan kapang yang cepat. Tempe yang berkualitas baik memiliki pH pada kisaran 6.3 hingga 6.5. Zainuddin (2019) menyatakan sifat dari xanthan gum yang ditambahkan pada kopi pinogu yaitu kelarutan dan kestabilannya sangat baik pada kondisi asam dan basa sehingga larutan kopi bersifat homogen. Pada proses pembuatan susu tempe, perlu ditambahkan bahan penstabil untuk menghasilkan susu tempe yang berkualitas. Zainuddin (2014b) menyatakan bahwa fungsi bahan penstabil adalah mencegah pengendapan pada proses pembuatan susu kedelai. Salah satu bahan penstabil yang dapat digunakan pada susu dari kedelai adalah xanthan gum. Salah satu karakteristik dari xanthan gum adalah viksositasnya sangat stabil pada berbagai $\mathrm{pH}$ dan temperatur. Berdasarkan hal tersebut, penulis tertarik untuk melakukan penelitian ini dengan 
tujuan untuk mengetahui hasil analisa stabilitas, kadar protein, dan kadar air pada susu tempe dengan penambahan xanthan gum dan mengetahui hasil analisa organoleptik pada susu tempe dengan penambahan xanthan gum.

\section{METODOLOGI}

Bahan yang digunakan adalah tempe kedelai, air, xanthan gum, $\mathrm{H}_{2} \mathrm{SO}_{4}$, aquades, $\mathrm{H}_{2} \mathrm{BO}_{3}, \mathrm{HCl}$, dan $\mathrm{NaOH}$. Alat yang digunakan adalah pisau, panci, talenan, blender, timbangan, kompor, wadah gelas, pengaduk, stopwatch, sendok, ayakan 80 mesh, cawan, oven, labu, erlemeyer dan pipet.

Prosedur pengolahan susu tempe mengacu pada Hapsari (2013) yaitu : Tempe sebanyak 250 gram dipotong kecil-kecil seukuran $1 \mathrm{~cm}$ persegi dan dicuci dengan air mengalir. Potongan tempe diblansir pada suhu $80-100^{\circ} \mathrm{C}$ selama 10 menit. Tempe ditiriskan sampai kering, lalu digiling dan diblender dengan menambahkan air hangat $40^{\circ} \mathrm{C}$. Larutan tempe ditambahkan air hangat 1liter dan disaring dengan dua kali penyaringan. Penyaringan pertama dengan saringan biasa dan penyaringan kedua disaring dengan kain kasa. Susu tempe direbus sambil aduk sampai mendidih dengan suhu $90-100^{\circ} \mathrm{C}$ selama 5 menit. Susu tempe didinginkan selama 30 menit. Susu tempe ditambahkan bahan penstabil xanthan gum.

Perlakuan yang digunakan pada penelitian ini adalah perbandingan susu tempe $100 \mathrm{ml}$ dengan variasi penambahan kosentrasi xanthan gum. Konsentrasi xanthan gum yang digunakan mengacu pada Zainuddin (2014a), pada produk susu kedelai yaitu :
PO = tanpa xanthan gum
$\mathrm{P} 1=$ konsentrasi xanthan gum $0,25 \mathrm{~g}$
P2 = konsentrasi xanthan gum $0,5 \mathrm{~g}$
P3 = konsentrasi xanthan gum $0,75 \mathrm{~g}$
P4 = konsentrasi xanthan gum $1 \mathrm{~g}$

Penelitian ini menggunakan Rancangan Acak Lengkap (RAL) dengan 5 perlakuan dan 3 kali ulangan, kemudian data diolah dalam analisis sidik ragam dengan menggunakan aplikasi SPSS. Rumus persamaan matematisnya sebagai berikut:

$$
\begin{aligned}
& \multicolumn{1}{c}{\mathrm{Y}_{\mathrm{ij}}=\mu_{\mathrm{i}}+\mathrm{a}_{\mathrm{i}}+\varepsilon_{\mathrm{ij}}} \\
\text { Keterangan : } \mathrm{Y}_{\mathrm{ij}} & =\text { hasil pengamatan } \\
\mu_{\mathrm{i}} & =\text { rataan } \\
\mathrm{a}_{\mathrm{i}} & =\text { lama fermentasi ke-i } \\
\varepsilon_{\mathrm{ij}} & =\text { galat }
\end{aligned}
$$

Apabila hasil pengujian menunjukkan pengaruh yang nyata, maka analisis data dilanjutkan dengan uji beda jarak nyata Duncan.

\section{Parameter Pengamatan \\ Kadar Air (Sudarmadji, 1997)}

Pengukuran kadar air sampel dilakukan dengan proses pengeringan. Prosedur kerja pengukuran kadar air adalah cawan kosong dan tutupnya dikeringkan dalam oven selama 15 menit, kemudian ditimbang dengan cepat kurang lebih $5 \mathrm{~g}$ sampel yang sudah dihomogenkan dalam cawan. Sampel dimasukkan dalam cawan dan di oven selama 3 jam, selanjutnya cawan didinginkan selama 3-5 
menit, setelah dingin bahan ditimbang. Bahan dikeringkan kembali dalam oven 30 menit sampai diperoleh berat konstan atau tetap. Kadar air dihitung dengan rumus:

$$
\% \text { Kadar Air : } \frac{\text { berat awal-berat akhir }}{\text { berat awal }} \times 100 \%
$$

\section{Kadar Protein (Sudarmadji, 1997)}

Prosedur kerja yang dilakukan pada penelitian ini adalah ditimbang kurang lebih 0,5 g sampel dimasukkan ke dalam labu khjedhal $100 \mathrm{ml}$, kemudian ditambahkan kurang lebih $1 \mathrm{~g}$ campuran selenium dan $10 \mathrm{ml} \mathrm{H}_{2} \mathrm{SO}_{4}$ pekat kemudian dihomogenkan. Didestruksi dalam lemari asam sampai jernih dan dibiarkan dingin, lalu dituang kedalam labu ukur $100 \mathrm{ml}$ ambil dibilas dengan aquades. Selanutnya Dibiarkan dingin kemudian ditambahkan aquadest sampai tanda tera, siapkan penampung yang terdiri dari dari $10 \mathrm{ml} \mathrm{H}_{2} \mathrm{BO}_{3} \%$ tambah 4 tetes larutan indicator dalam erlemeyer $100 \mathrm{ml}$. Dipipet $5 \mathrm{ml} \mathrm{NaOH} \mathrm{30 \%} \mathrm{dan} 100 \mathrm{ml}$ aquadest di suling hingga volume penampung menjadi kurang lebih $50 \mathrm{ml}$ dibilas ujung penyuling dengan aquades kemudian ditampung bersama isinya. Lalu dititrasi dengan larutan $\mathrm{HCl}$ atau $\mathrm{H}_{2} \mathrm{SO}_{4}$ 0,02 N. Perhitungan kadar protein dilakukan sebagai berikut :

$$
\% \text { Kadar Protein }=\frac{\text { V1 } \times \text { Normalitas } \mathrm{H}_{2} \mathrm{SO}_{4} \times 6,25 \times p}{\text { gram contoh }} \times 100 \%
$$

Keterangan :

$\mathrm{V} 1$ = volume titrasi $(\mathrm{ml})$

$\mathrm{N}=$ normalitas larutan $\mathrm{HCl}$ atau $\mathrm{H}_{2} \mathrm{SO}_{4} 0,02 \mathrm{~N}$

$\mathrm{P}=$ faktor pengenceran $=100 / 5$

\section{Stabilitas Seduhan}

Pengamatan stabilitas seduhan mulai dilakukan setelah minuman diseduh. Pengamatan dilakukan secara visual dengan menggunakan bantuan alat stopwatch, kemudian dicatat waktu hingga terbentuk endapan dan diukur tinggi endapannya. Pengukuran stabilitas dapat dihitung dengan rumus :

$$
\text { Stabilitas }=\frac{A-\mathrm{B}}{\mathrm{A}} \times 100 \%
$$

Keterangan : A = Total volume

\section{Uji Organoleptik}

$$
\mathrm{B}=\text { Total volume endapan }
$$

Parameter uji organoleptik yang dilakukan meliputi aroma dan rasa. Metode pengujian yang digunakan yaitu metode hedonik (uji kesukaan) dengan skala 1 sampai 5, yaitu (1) sangat tidak suka, (2) tidak suka, (3) agak suka, (4) suka, (5) sangat suka. Panelis yang digunakan adalah panelis belum terlatih sebanyak 20 orang untuk memberikan penilaian menurut tingkat kesukaannya terhadap aroma dan rasa susu tempe. Hasil skor uji organoleptik dirata-ratakan dan dianalisis secara deskriptif.

\section{HASIL DAN PEMBAHASAN}

\section{Kadar Air}

Air merupakan sumber nutrisi seperti bahan makanan lainnya. Keberadaan air sangat penting untuk keberlangsungan proses biokimiawi organisme hidup. Air dalam bahan pangan merupakan suatu komponen penting karena dapat mempengaruhi penampakan, tekstur, dan cita rasa makanan. Makanan kering 
sekalipun seperti buah, tepung, serta biji-bijian mengandung air dalam jumlah tertentu ( Winarno, 2004).

Kadar air susu tempe dengan variasi penambahan xanthan gum disajikan pada Gambar 1.

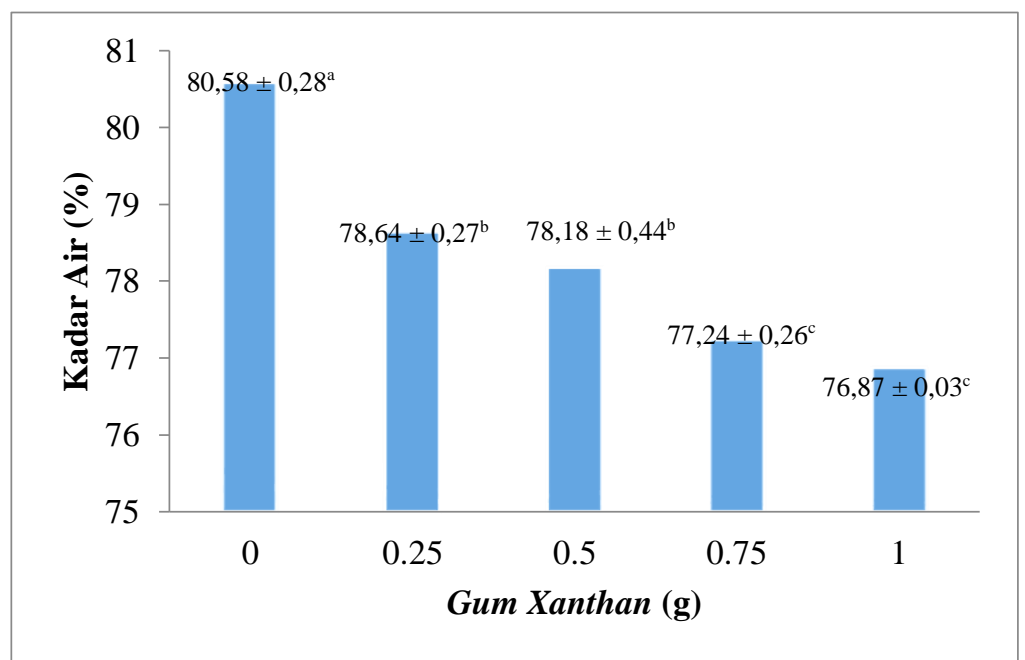

Gambar 1. Kadar Air Susu Tempe dengan Variasi Penambahan Xanthan gum

Berdasarkan Gambar 1, kadar air tertinggi terdapat pada susu tempe tanpa penambahan xanthan gum yaitu $80,58 \%$ dan dengan penambahan xanthan gum 0,25 g yaitu $78,64 \%$. Hasil analisis sidik raga menunjukkan bahwa penambahan xanthan gum pada susu tempe berpengaruh sangat nyata $(\mathrm{P}<0,01)$ terhadap kadar air susu tempe.

Hasil uji rata-rata antar perlakuan dengan menggunakan uji beda nyata Duncan menunjukkan bahwa kadar air susu tempe tanpa penambahan xanthan gum $(0 \mathrm{~g})$ berbeda sangat nyata $(\mathrm{P}<0,01)$ lebih tinggi dari susu tempe dengan penambahan 0,25 g, 0,5 g, 0,75 g, dan $1 \mathrm{~g}$ xanthan gum. Akan tetapi, penambahan xanthan gum $0,25 \mathrm{~g}$ dan $0,5 \mathrm{~g}$ tidak berbeda nyata $(\mathrm{P}>0,05)$ seperti halnya penambahan xanthan gum $0,75 \mathrm{~g}$ dan $1 \mathrm{~g}$. Hal ini karena xanthan gum merupakan polisakarida yang memiliki gugus polar sehingga air dapat membentuk ikatan hidrogen dengan gugus hidroksil $(-\mathrm{OH})$ pada xanthan gum. Selain itu, xanthan gum memiliki kemampuan untuk mengikat air hingga 32.300 \pm 1100 g H2O/100 gram solid seperti yang dikemukakan oleh Cui (2000). Kemampuan pengikatan air $x a n t h a n$ gum ini dapat mengakibatkan penurunan volume dan penguapan kadar air, sehingga air bebas yang teruapkan menjadi berkurang. Penelitian ini sesuai dengan hasil penelitian yang dilakukan Ramadhan et al et al (2015) yang mengkaji pengaruh variasi penambahan xanthan gum terhadap sifat fisik dan kimia serta organoleptik fruit leather kulit buah naga daging super merah (Hylocereus costaricensis).

\section{Kadar Protein}

Protein merupakan salah satu kelompok bahan makronutrien. Protein berperan lebih penting dalam pembentukan biomolekul dari pada sebagai sumber energi. Namun demikian, apabila organisme sedang kekurangan energi maka protein terpaksa dapat juga dipakai sebagai sumber energi (Zainuddin, 2014b).

Kadar protein susu tempe dengan variasi penambahan xanthan gum disajikan pada Gambar 2. 


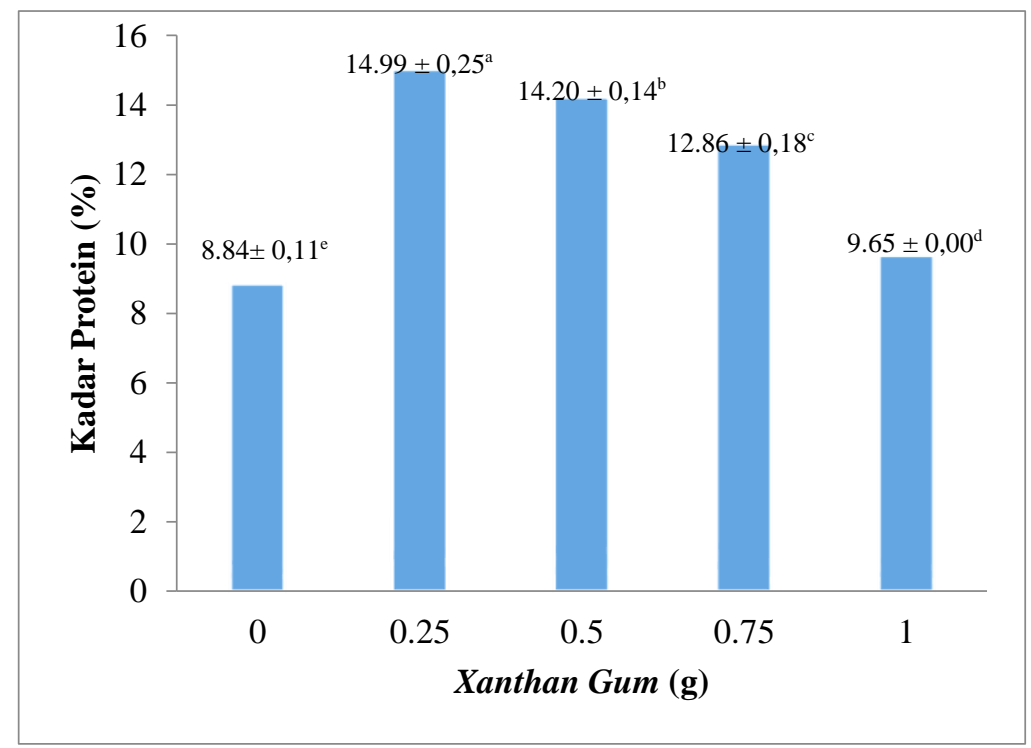

Gambar 2. Kadar Protein Susu Tempe dengan Variasi Penambahan Xanthan gum

Berdasarkan Gambar 2, kadar protein tertinggi terdapat pada susu tempe tanpa penambahan xanthan gum yaitu $14,99 \%$ dan dengan penambahan xanthan gum $0,25 \mathrm{~g}$ yaitu 14,2\%. Hasil analisis sidik ragam menunjukkan bahwa penambahan xanthan gum pada susu tempe berpengaruh sangat nyata $(\mathrm{P}<0,01)$ terhadap kadar protein susu tempe.

Hasil uji rata-rata antar perlakuan dengan menggunakan uji beda nyata Duncan menunjukkan bahwa kadar protein susu tempe tanpa penambahan xanthan gum $(0 \mathrm{~g})$ berbeda sangat nyata $(\mathrm{P}<0,01)$ lebih rendah dari susu tempe dengan penambahan $0,25 \mathrm{~g}, 0,5 \mathrm{~g}, 0,75 \mathrm{~g}$, dan $1 \mathrm{~g}$ xanthan gum. Hal ini diduga karena struktur Xanthan gum memiliki gugus gula yang meruah. Sehingga semakin banyak penambahan Xanthan gum pada perlakuan akan menyebabkan gugusan gula yang meruah pada Xanthan gum menghalangi atau menutupi atom $\mathrm{N}$ pada struktur polipeptida (Sastrohamidjojo, 2005). Hal ini mengakibatkan pada pengukuran $\mathrm{N}$ total protein yang merupakan prinsip dasar dari analisis protein secara Kjedahl semakin menurun.

\section{Stabilitas Seduhan}

Susu tempe dengan stabilitas terbaik memiliki laju pengendapan terendah, artinya dibutuhkan waktu lebih lama bagi suspensi untuk terpisah dan membentuk sedimen. Berdasarkan pengamatan secara visual, dilakukan perhitungan persentasi stabilitas berdasarkan perbandingan total volume dan total endapan susu tempe yang ditampilkan dalam bentuk grafik seperti pada Gambar 3.

Stabilitas tertinggi terdapat pada susu tempe dengan penambahan xanthan gum 1 g yaitu 98\%. Hal ini diduga karena penambahan xanthan gum dapat membentuk helix dengan kelompok sulfat bermuatan negatif, dimana helix ini akan berinteraksi dengan partikel protein dalam susu hingga batas tertentu dan mencegah terjadinya sedimentas. Selain itu, Zainuddin (2014a) mengemukakan bahwa penambahan xanthan gum dapat meningkatkan viskositas larutan yang erat kaitannya dengan kadar air dan stabilitas susu kedelai. Dalam hal ini, semakin banyak xanthan gum yang ditambahkan maka akan semakin meningkatkan viskositas susu tempe, menurunkan kadar air, dan meningkatkan stabilitas susu 
tempe. Penelitian ini sesuai dengan hasil penelitian yang dilakukan Ramadhan et al (2015).

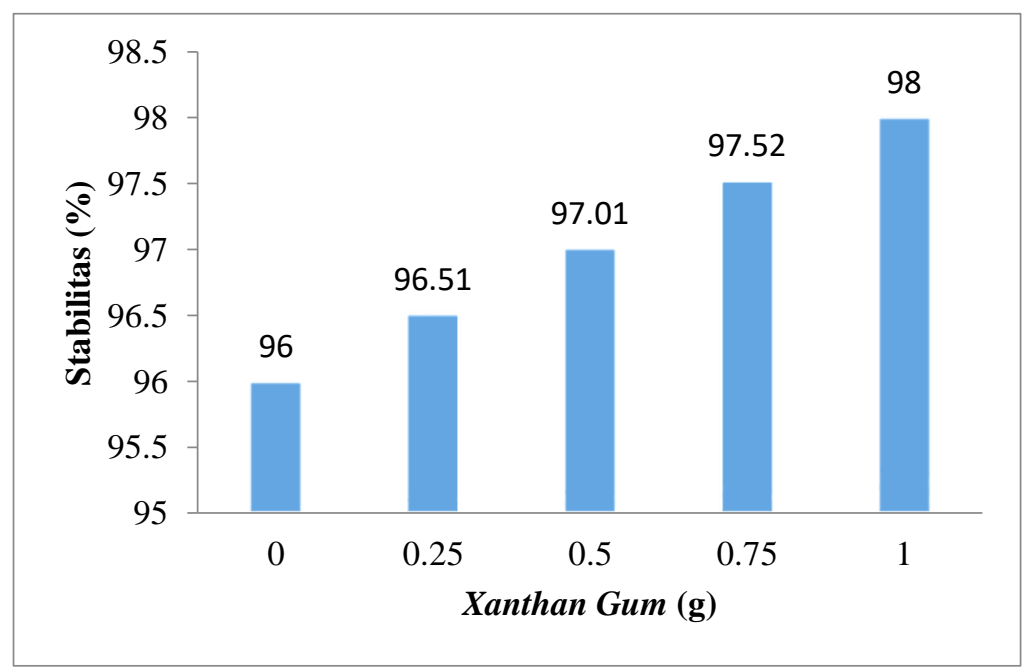

Gambar 3. Stabilitas Susu Tempe dengan Variasi Penambahan Xanthan gum

\section{Uji Organoleptik}

\section{Aroma}

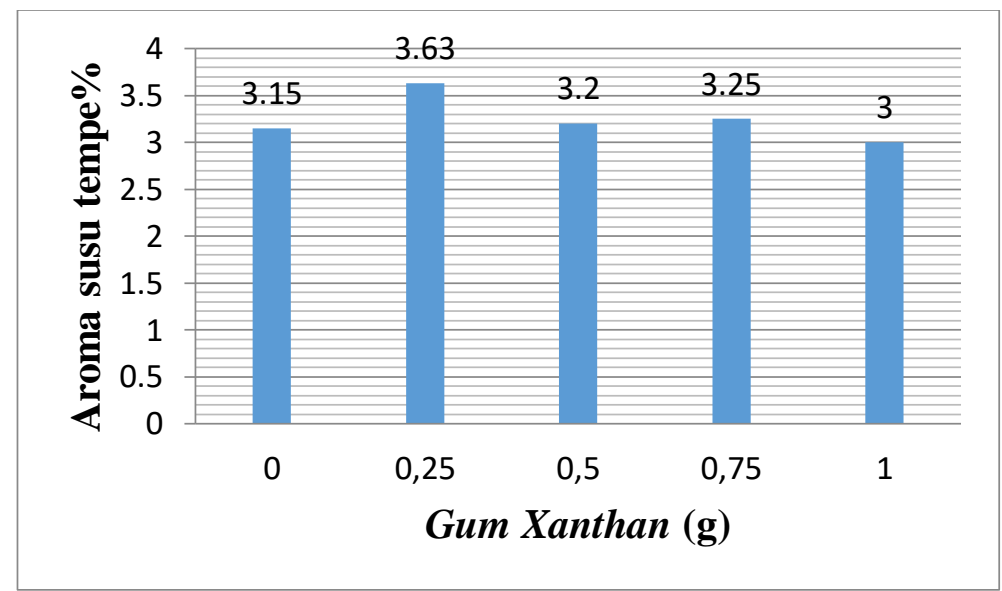

Gambar 4. Rataan Skor Aroma Susu Tempe

Aroma umumnya didapat dengan mengenali hasil penciuman. Aroma mempunyai peranan yang sangat penting dalam penentuan derajat penilaian dan kualitas suatu bahan pangan. Selain bentuk dan warna, aroma akan berpengaruh dan menjadi perhatian utama. Setelah aroma diterima maka penentuan selanjutnya adalah cita rasa. Adapun aroma khas yang dimiliki oleh susu tempe yaitu aroma langu. Timbulnya aroma ini disebabkan oleh kerja enzim lipoksigenase yang bereaksi dengan lemak sewaktu dinding sel kedelai pecah oleh penggilingan, terutama jika penggilingan dilakukan secara basah dengan suhu dingin (Winarno, 2004).

Berdasarkan Gambar 4, panelis lebih banyak menyukai aroma susu tempe dengan penambahan xanthan gum 0,25 g dengan nilai 3,63. Menurut Bylaite (2005) dalam Ramadhan et al (2015) penambahan hidrokoloid akan menurunkan penerimaan terhadap atribut aroma. Penurunan tingkat penerimaan atribut aroma ini mungkin merupakan hasil dari dua mekanisme utama yaitu penurunan tingkat 
difusi di media karena solusi peningkatan viskositas dan adanya interaksi komponen aroma dan unsur pokok dari matrik hidrokoloid.

\section{Rasa Susu Tempe}

Rasa adalah faktor yang mempengaruhi penerimaan produk makanan. Cita rasa bahan pangan sesungguhnya terdiri dari 3 komponen yaitu bau, rasa, dan rangsangan mulut (Winarno, 2004). Hasil uji organoleptik terhadap rasa susu tempe dapat dilihat pada Gambar 5.

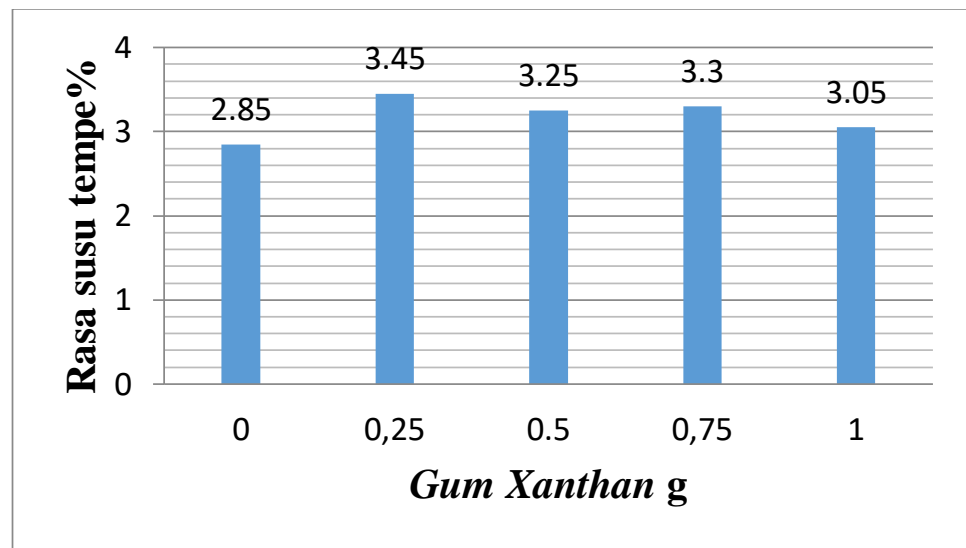

Gambar 5.Grafik Uji Organoleptik pada Rasa Susu Tempe

Berdasarkan Gambar 5, panelis lebih banyak menyukai rasa susu tempe dengan penambahan xanthan gum 0,25 g dengan nilai 3,45. Rasa yang ditimbulkan oleh xanthan gum berupa rasa asam, karena xanthan gum merupakan hasil fermentasi dari mikroorganisme dengan bahan baku glukosa dan sukrosa. Winarno (2004) mengemukakan bahwa rasa atau cita rasa sangat sulit dimengerti secara ilmiah, karena selera manusia berbeda. Rasa merupakan salah satu faktor dalam menentukan mutu bahan makanan yang umunya ditentukan oleh indra manusia melalui kuncup-kuncup cicipan seseorang menelan makanan tersebut.

\section{KESIMPULAN}

Berdasarkan hasil dan pembahasan, maka dapat disimpulkan bahwa :

1. Pembuatan susu tempe dengan penambahan xanthan gum berpengaruh sangat nyata $(\mathrm{P}<0,01)$ terhadap kadar air, kadar protein, dan stabilitas susu tempe. Kadar air tertinggi dihasilkan pada susu tempe dengan tanpa penambahan xanthan gum yaitu $80,58 \%$ dan protein tertnggi pada penambahan Xanthan gum $0,25 \%$ sedangkan stabilitas tertinggi dihasilkan pada susu tempe dengan penambahan xanthan gum $1 \%$.

2. Susu tempe yang paling disukai oleh panelis yaitu susu tempe dengan penambahan xanthan gum $0,25 \%$.

\section{DAFTAR PUSTAKA}

Astawan M., 2004. Tetap Sehat dengan Produk Makanan Olahan. Tiga Serangkai. Solo.

Bylaite, E., Jens A.N., and Anne S. M., 2005. Effect of Xanthan on Flavor Release from Thickened Viscous Food Model Systems. Food Biotechnology and Engineering Group,Bio Centrum-DTU, Soeltofts Plads, Building 221, Technical University of Denmark, DK-2800 Kgs. Lyngby. 
Cui., 2000. Polysaccharide Gums from Agricultural Products : Processing, Structures and Functionality. CRC Press.

Hapsari, T.P dan M. Saihullah., 2013. Pembuatan Susu Tempe Kajian Lama Fermentasi Tempe dan Penggunaan Carboxymethyl cellulose (CMC). Jurnal; Teknologi Pengajar Vol. 5 No.1. Fakultas Pertanian Universitas Yudharta Pasuruan.

Mujianto, 2013. Analisis Faktor yang Mempengaruhi Proses Produksi Tempe Produk UMKM di Kabupaten Sidoarjo. Jurnal Reka Agroindustri Media Teknologi dan Manajemen Agroindustri. Vol. No. 1.

Nouts, M. J. R., J. L. Kiers., 2005. A review Tempe Fermentation, Innovation and Functionality. Update into thr third Millenium. Journal of Applied Microbiology. 98, 789-805.

Ramadhan,K., Windi A.,dan Esti W., 2015. Kajian Pengaruh Variasi Penambahan Xanthan Gum terhadap Sifat fisik dan Kimia serta Organoleptik Fruit Leather Kulit Buah Naga Daging Super Merah (Hylocereus costaricensis). Jurnal Teknologi Hasil Pertanian, Vol. VIII, No.2.

Sastrohamidjojo, H., 2005. Kimia Organik Stereokimia, Karbohidrat,Lemak dan Protein. UMG Press. Yogyakarta.

Sudarmadji S.,1997. Prosedur Analisa untuk Bahan Makanan dan Pertanian. Liberty. Yogyakarta.

Widowati, S., 2005. Tempe dan Produk Turunannya. Pangan Fungsional Indigenous Indonesia. Prosiding Seminar Nasional Peningkatan Daya Saing Pangan Tradisional. Balai Besar Penelitian dan Pengembangan Pascapanen Pertanian. Hal 220-228 Proceeding, International Tempe Symposium. Juli 13-15 1997.

Winarno., 2004. Kimia Pangan dan Gizi. Gramedia Pustaka Utama. Jakarta.

Zainuddin, A., 2014a. Analisis dan Aplikasi Gum Xanthan terhadap Produk Susu Kedelai. Jurnal Agrokompleks, 3 (7), 2-9.

Zainuddin, A., 2014b. Teknologi Pangan. Idea Press. Yogyakarta.

Zainuddin, A., 2020. Aplikasi Xanthan Gum Terhadap Sifat Kehomogenan dan Citarasa Kopi Pinogu. Jurnal Agercolere, 2 (1), 1-5. 